\title{
Global monitoring data shows grain size controls turbidity current structure
}

D. Vendettuoli ${ }^{1-2}$, M. A. Clare ${ }^{1}$, E.J. Sumner ${ }^{2}$, M.J.B. Cartigny ${ }^{3}$, P.J. Talling ${ }^{3}$, J. Wood ${ }^{4}$, L.P. Bailey ${ }^{1-2}$, M. Azpiroz - Zabala ${ }^{5}$, C.K. Paull ${ }^{6}$, R. Gwiazda ${ }^{6}$, J.P. Xu ${ }^{7}$, C. Stacey ${ }^{8}$, D.G. Lintern $^{8}$, S.M. Simmons ${ }^{9}$, E.L Pope ${ }^{3}$ and S. Hage ${ }^{10}$

${ }^{1}$ National Oceanography Centre, University of Southampton, Waterfront campus, Southampton SO14 3ZH, UK

${ }^{2}$ School of Ocean and Earth Science, University of Southampton, Southampton, SO14 3ZH, UK

${ }^{3}$ Department of Earth Sciences and Geography, Durham University, Durham DH1 3LE, UK

${ }^{4}$ Ocean Data Technologies, Inc., 31 School Street Hyannis, MA 02601

${ }^{5}$ Faculty of Civil Engineering and Geoscience, Delft University of Technology, $2628 \mathrm{CN}$ Delft, The Netherlands

${ }^{6}$ Monterey Bay Aquarium Research Institute (MBARI), 7700 Sandholdt Rd, Moss Landing, CA 95039, USA

${ }^{7}$ Southern University of Science and Technology, Shenzhen, China

${ }^{8}$ Geological Survey of Canada, Institute of Ocean Science, Canada

${ }^{9}$ Energy and Environment Institute, University of Hull, Hull, HU6 7RX, U.K.

${ }^{10}$ Department of Geoscience, Calgary University, AB Canada

Corresponding author: Daniela Vendettuoli (d.vendettuoli@soton.ac.uk)

\section{Key Points:}

- Turbidity currents have two end-member structures that depend mainly on grain size.

- Short-lived sandy flows last for minutes to hours and velocity decays exponentially over time.

- Muddy flows can be far more prolonged and develop near-constant velocity for days. 



\section{Key words}

Turbidity currents structure; maximum flow velocity; end-members; grainsize

\section{Introduction}

Until recently, few direct measurements existed for powerful sediment avalanches on the seafloor, known as turbidity currents. It is important to understand these flows, as they play a key role in sediment and nutrient transfer to the deep sea, thereby affecting global geochemical cycling (Schlunz et al., 2000; Talling, 2014; Rabouille et al., 2017). Turbidity currents are challenging to measure because they occur on the seafloor, are destructive, often highly unpredictable (Inman et al., 1976; Talling et al., 2013; Xu et al., 2010; Paull et al., 2018) and pose a hazard to critical seafloor infrastructure (Carter et al., 2014). Despite these challenges, the last decade has seen a growth in the seafloor monitoring of turbidity currents (Clare et al., 2020 and references therein); providing the first detailed insights into the structure of these flows. These monitoring studies have led to several new models for turbidity current dynamics (e.g. Azpiroz-Zabala et al., 2017; Symons et al., 2017; Heerema et al., 2020), that test aspects of previous influential models (e.g. Bagnold, 1962; Middleton, 1966; Parker et al., 1986; Cantero et al., 2012).

Previous flow monitoring studies have typically focused on data-sets from individual canyons, and have focused on the characteristics of site-specific flows (e.g. Talling et al., 2013, Clare et al., 2020 and references therein). However, there is now flow monitoring data from different sites worldwide, which allows consideration of general questions about the dynamics of turbidity currents. For example, why do some flows maintain a fixed velocity for several days, while other flows rapidly accelerate but then dissipate within minutes to hours? What internal or external factors determine flow behavior? There are fundamental gaps in understanding of how the structure of turbidity currents varies, and the physical controls on that variability.

Many classification systems exist for turbidity currents, based upon either their deposits or scaled-down laboratory experiments (e.g. Lowe, 1979b; Postma, 1986; Mulder and Cochonat, 1996; Haughton et al., 2009; Talling et al., 2012). The nature of triggers and flow initiation has been suggested as a strong control on the structure of turbidity currents. For instance, Mulder et al. (2003) proposed that flows in muddy river-fed systems differ from that in more dilute river-fed settings or littoral drift-fed canyons. In such classifications, initiation through a rapid slope collapse may form a short-lived, unsteady surge, while sustained sediment input (such as 
during sediment-laden river flood discharge to the ocean) may result in a prolonged, more steady flow (e.g. Middleton and Hampton, 1976; Kneller and Branney, 1995; Khripounoff et al., 2012). Others suggest that flow behavior relates to physiographic controls such as canyon or channel morphology (Xu et al., 2010), shelf gradient (Talling et al., 2007), or the grain size present in the system (e.g. Stow and Bowen, 1980; Lowe, 1982; Mutti et al., 2003).

In the past, a lack of detailed monitoring data has limited the ability to test models using data from full-scale turbidity currents. Here, for the first time, we take advantage of detailed turbidity current monitoring data from recent studies worldwide to understand the physical controls on turbidity current structure. Specifically, the first aim is to document the variability in turbidity current structure, especially duration and temporal evolution of velocity. We analyse whether there are distinct types of flow, or if a continuum exists between end members. Second, we investigate the physical controls on the different types of observed flow structures, including system type, triggers, flow initiation and grain size. We compare turbidity currents in systems linked to muddy and sandy rivers, and systems fed by longshore drift. The range of systems varies from small fjord-head channels to large deep-sea submarine canyons.

\section{Data}

To assess the diversity in the structure of turbidity currents, we analyse high-resolution depthresolved velocity measurements of turbidity currents from seven sites worldwide. These sites span a wide range of environments, including bedload dominated fjord-head delta systems, river-fed deep-sea canyons, and littoral-fed deep-sea canyons. In all but one of the datasets, flow velocities were recorded using downward-looking Acoustic Doppler Current Profilers (ADCPs), at sites from $60 \mathrm{~m}$ to 2,300 $\mathrm{m}$ water depth. In one dataset (from offshore West Papua), a single-point current meter was used (see Table S1 and Table S2 in the supplementary material for full details of data acquisition). We now briefly introduce the different systems to provide context for later discussion (Figure S2).

\subsection{Bedload dominated fjord-head delta systems}

Howe Sound and Bute Inlet in British Columbia are relatively deep and steep-sided fjords, which host active submarine channels that are fed by one or more rivers at the fjord-heads (Gales et al., 2019). Squamish Prodelta is located at the mouth of the Squamish River in Howe Sound, where it connects to three submarine channels that reach water depths of c.200 m (Hughes Clarke, 2016). Here we analyse ADCP measurements, collected in 2015 (Hage et al., 
2018), that recorded $300 \mathrm{~m}$ downstream of the delta-lip, at a water depth of $60 \mathrm{~m}$. In Bute Inlet, Homathko and Southgate Rivers connect to a submarine channel that extends c. $40 \mathrm{~km}$ to c.600 $m$ water depth (Prior et al., 1986). Turbidity currents were measured in 2016 using an ADCP located $\sim 20 \mathrm{~km}$ downstream of the delta lip in $480 \mathrm{~m}$ water depth. Sediment cores in the axes of both channels generally recovered massive sands, although mud-caps are common in cores in Bute Inlet (Zeng et al., 1991; Vendettuoli et al., 2019; Hage et al., 2019; 2020).

\subsection{River-fed deep-sea submarine canyons}

The head of the Congo Canyon, located offshore Angola, is directly connected to the Congo river and located within the estuary (Savoye et al., 2009). Flows were recorded between 2009 and 2010 by an ADCP deployed at 2,000 m water depth (Cooper et al., 2012; Azpiroz-Zabala et al., 2017). Deposits on the canyon floor consist of laminated sediments mainly composed of clay and silt, organic matter, with a minor component of sand (Dennielou et al., 2017; AzpirozZabala et al., 2017). The Var submarine canyon is located in the northwest Mediterranean Sea, at the outflow of the Var River (Khripounoff et al., 2009). Turbidity currents were recorded from 2005-2008 by an ADCP located at 1,200 m water depth (Khripounoff et al., 2009). Sediment traps from the same location recovered fine to very-fine sand (Khripounoff et al., 2012). A sinuous submarine canyon extends from the Wanggar River delta in Cenderawasih Bay, West Papua, to c.1,600 m water depth. Near-bed velocity data were collected in 2012 using an Aanderaa RCM-9 single-point current meter positioned $10.3 \mathrm{~m}$ above the seabed at a location $10 \mathrm{~km}$ outside of the channel lobe axis in $1520 \mathrm{~m}$ water depth (Wood, 2013). Sediment cores recovered a range of grain sizes including sand (within the main channel axis) but were dominated by mud and woody organic debris (Orange et al., 2010), particularly in the lobe fringes where the current meter was located.

\subsection{Oceanographically-fed submarine canyons}

Monterey Canyon offshore California is fed by long-shore drift, with negligible river input (Paull et al., 2005). While the canyon extends to 3,600 m water depth, we focus on turbidity currents recorded in the upper Monterey Canyon measured by an array of ADCPs deployed from 2016-2018 in water depths between $200 \mathrm{~m}$ and $1850 \mathrm{~m}$ (Paull et al., 2018; Heerema et al, 2020). Core samples from the floor of Monterey Canyon dominantly comprise coarse sand and gravels (Paull et al., 2005; Maier et al., 2019). Hueneme Canyon, offshore Southern California, is also an efficient trap for sands transported by littoral drift, although, the Santa Clara River is also an important source of sediment input (Xu et al., 2010). Turbidity currents were recorded 
by an ADCP located at $188 \mathrm{~m}$ water depth, where sediment traps mainly captured fine sand (Xu et al., 2010).

\section{Methodology}

We characterize the structure of each measured turbidity current using the temporal evolution of the maximum velocity and the total flow duration. We primarily use ADCP data in our analysis because the depth-resolved velocity measurements allow us to plot the maximum velocity despite the height of the velocity maximum changing through time. Raw ADCP data at Squamish Prodelta, Bute Inlet, Congo Canyon and Monterey Canyon permit such detailed velocity analysis. We also compare our results with measurements from published data that do not permit us to be as precise, as flow velocity was only reported at fixed heights within the water column (i.e. ADCP measurements in Var and Hueneme Canyons and fixed current meter in Cenderawasih Bay; Table S1), but still provide a valid comparison with different system types (see Figure S3 in the supplementary material).

\subsection{Ensuring consistent identification of the start and end of turbidity currents}

For each of the individual flow time series, we identified the starting point of turbidity currents. The start of a flow is straightforward to recognize, as it is the point in time that features a rapid increase in the downstream velocity. Defining the end of a turbidity current is more difficult. To be consistent among the datasets, we apply a cut off at the point where downstream flow velocity is less than the average background velocity, plus or minus one standard deviation. We define background velocity as the ambient range of velocities that precedes the start of each event (See Figure S2 and supplementary material for details).

\subsection{Standardizing the sampling frequency of velocity measurements}

The temporal resolution of the data varies among the different sites depending on the configuration of the monitoring instruments (i.e. from every 1 second at Squamish Prodelta to every 30 minutes in Var Canyon; Table S2). In order to standardize the datasets, we subsampled the velocity of all of the events detected at each location relative to flow duration such that all datasets have 50 measurements regularly-spaced over the total duration of each flow (Figure $1 \&$ S2). 

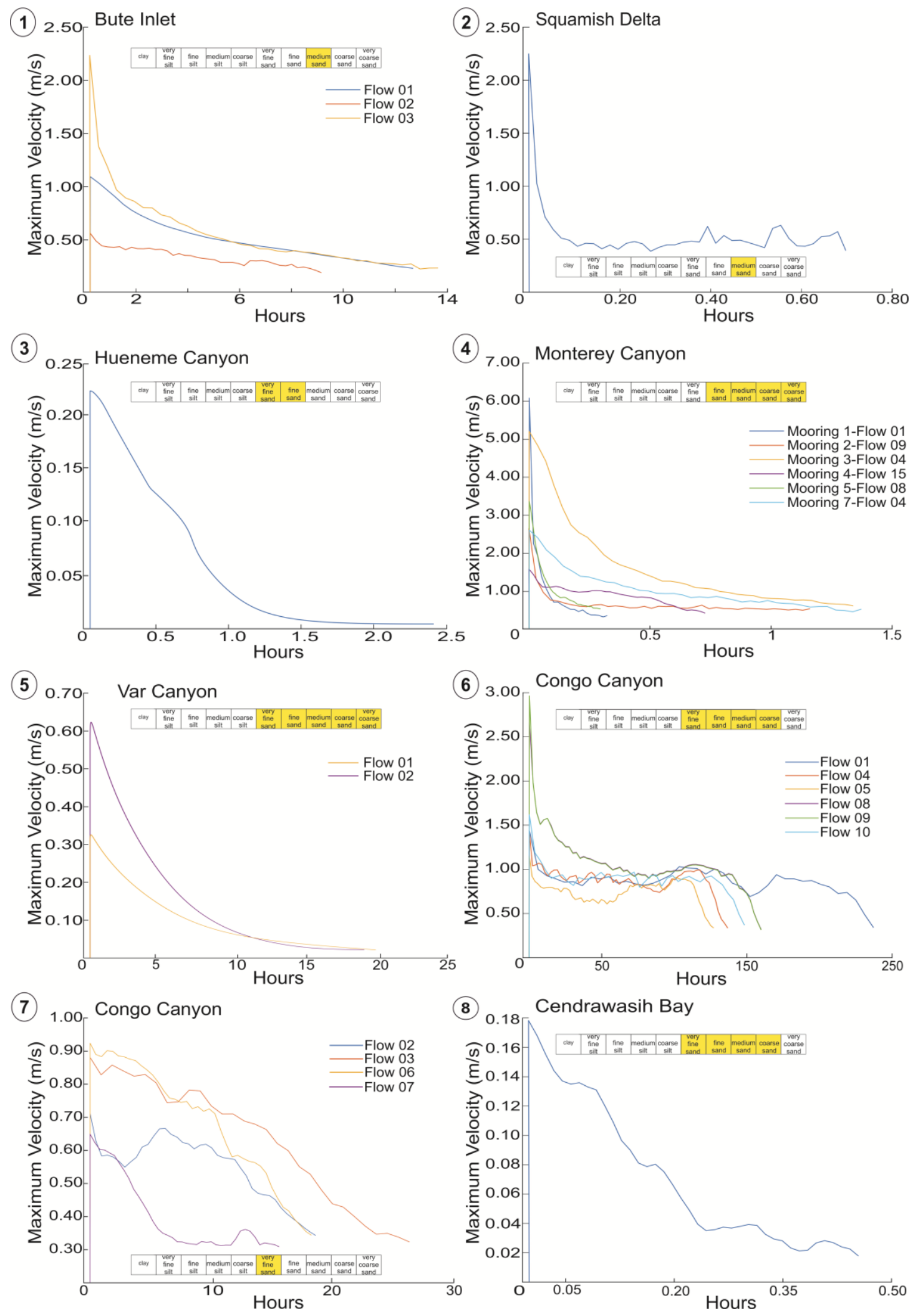

Figure 1: maximum velocity and time plotted for the different turbidity currents events detected at the different sites worldwide with the indication of the grainsize transported down-slope (refer to Table $1 \& 2$ for the reference on the study of each site) 
This methodology, means that the velocity-time plots of flows that were initially sampled with a higher resolution will be artificially smoothed. Our intention here, however, is to examine broad trends in velocity evolution over time. Therefore, it is important to ensure we provide a consistent comparison among all of the individual flows and across the different settings.

\subsection{Normalized time-velocity plots}

In order to compare trends in the temporal evolution of flow velocity, we plot normalized timevelocity graphs. In these plots, the velocity of each individual event is normalized relative to its peak velocity, with time normalized to total flow duration (Figure 2 - Panel A).

\subsection{Calculation of bed shear stress}

To investigate the role of grainsize on the structure of the turbidity currents, we estimate the bed shear stress (Figure 3b) using:

$$
\mathrm{U}^{*}=\mathrm{U}_{\max } \mathrm{K}\left[\ln \left(\mathrm{h}_{\max } /\left(0.1 \mathrm{D}_{90}\right)\right)\right]^{-1}
$$

Where, $U_{\max }$ is the maximum flow velocity $(\mathrm{m} / \mathrm{s}), \mathrm{K}$ is the Van Karman constant of $0.4, \mathrm{~h}_{\max }$ is the height of the maximum velocity $(\mathrm{m})$, and $\mathrm{D}_{90}$ is the ninetieth percentile of the grain size distribution in microns.

\section{Results}

\subsection{Two end-members in turbidity current structure}

Our results show that the velocity evolution of all of the turbidity currents monitored at the different locations fall between two end-members (Figure 2a). 

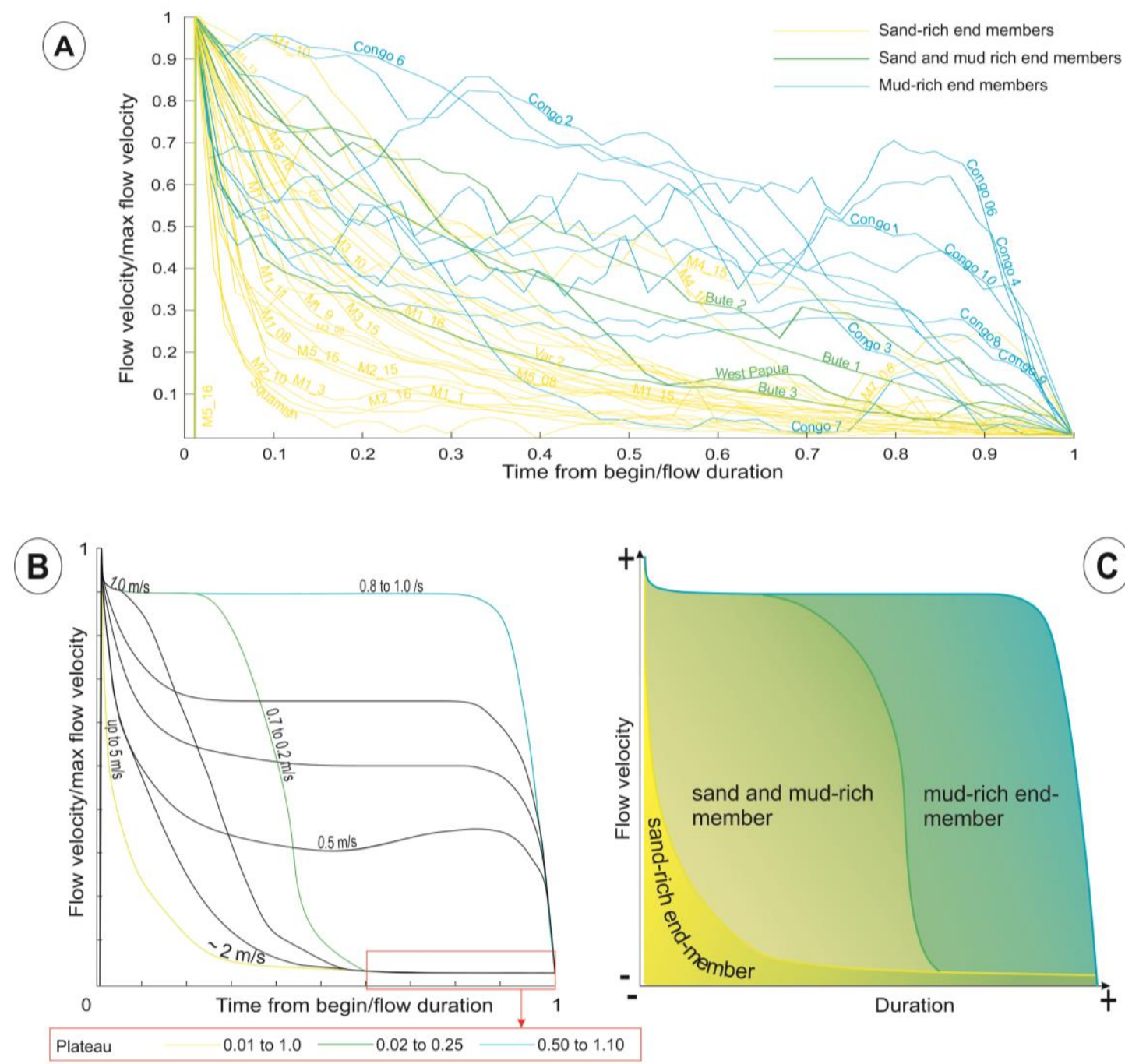

(D)
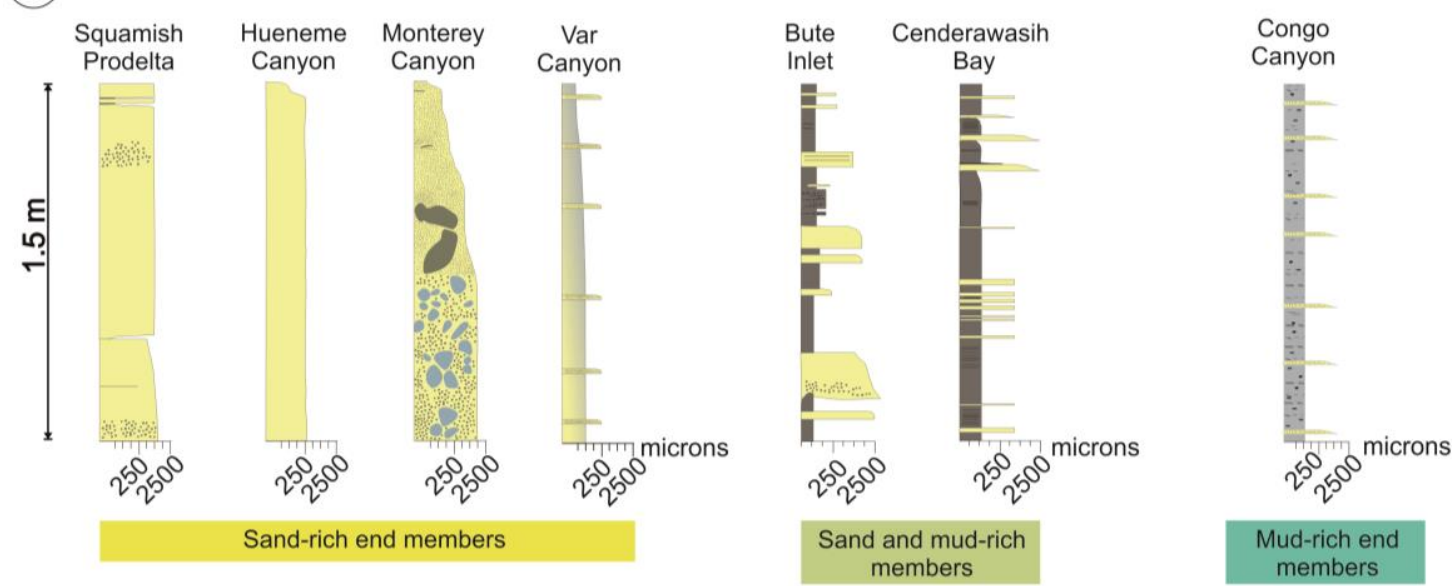

Figure 2: A) Normalized time-velocity plots for all of the turbidity currents events occurring at different locations worldwide; B) Normalized time-velocity graph that simplifies the above insert A. Numbers within the plot indicate the value of the maximum velocity detected from the ADCPs along the different portions of the flows; C) Schematic layout of the main end-member turbidity currents as defined in this study; D) core logs sampled at the different physiographic systems. See Table 3 of the supplementary material for the detailed description of such core logs and the reference to their study. 
The first end-member is characterized by flows that feature a rapid, near instantaneous, peak in velocity followed by an exponential decay. These events last from 42 minutes to 20 hours, and their peak velocity varies from $0.25 \mathrm{~m} / \mathrm{s}$ to $5 \mathrm{~m} / \mathrm{s}$. The second end-member is represented by turbidity currents that initially show a similar trend (i.e. an increase in velocity followed by an exponential decrease that lasts up to $30 \%$ of the total flow duration). However, instead of continuing the exponential decay, these flows display a plateau of near-constant velocity (Figure $2 \mathrm{~b}$ ). Durations for this second type of flow are markedly longer, lasting for $\sim 8$ days (from 6 minimum to 10 days as maximum), with constant plateau velocities lasting for $\sim 110$ hours (from a minimum of 70 hours to a maximum of 150 hours). The peak velocities it is $\sim 2.25 \mathrm{~m} / \mathrm{s}$ (minimum of $1.5 \mathrm{~m} / \mathrm{s}$ to a maximum of $3 \mathrm{~m} / \mathrm{s}$ ), reducing to $\sim 0.75 \mathrm{~m} / \mathrm{s}$ (from a minimum of $0.5 \mathrm{~m} / \mathrm{s}$ to a maximum of $1 \mathrm{~m} / \mathrm{s}$ ) in the plateau-like part of the flow. The nearconstant velocity plateaus are characterized by bed shear stresses in the range of $\sim 0.012 \mathrm{~m} / \mathrm{s}$ (from a minimum of 0.008 to a maximum of $0.016 \mathrm{~m} / \mathrm{s}$ ).

\subsection{Spectrum of flow behavior between the two end-member types}

Normalized time-velocity plots (Figure 2a) suggest that there is a continuous spectrum of behavior between these two end members. Short-lived (minutes to hours) turbidity currents, which occur in sandy systems (e.g. Squamish Prodelta, Monterey Canyon), have behavior that is closest to the first end-member (i.e. rapid increase, followed by swift exponential decay in velocity). Longer duration (days to weeks) turbidity currents in mud-rich systems (e.g. Congo Canyon) show a plateau-like, more stable velocity in their latter stages that characterizes the second end member. Flows that show intermediate behavior between these two end-members come from sites with mixed grain sizes (e.g. Cenderawasih Bay, Bute Inlet). Such events feature a rapid increase of the maximum velocity followed by an exponential decay that lasts for about $30 \%$ of the entire flow duration. Once the velocity reaches $2 / 3$ of its maximum, the decay then precedes with a downward concave trend until it reaches its minimum and plateaus to zero. The duration of such flows varies from 27 minutes to up to 2 days and the maximum velocity ranges from $0.18 \mathrm{~m} / \mathrm{s}$ to $1 \mathrm{~m} / \mathrm{s}$.

\section{Discussion}

Here we discuss why two end-members in turbidity current structure exist, and which physical processes determine where a particular flow lies on the spectrum between end-members. 


\subsection{Flow structure is independent of triggering mechanisms and system physiography}

Turbidity current structure has previously been attributed to several factors, such as the physiography of the system (Xu et al., 2010; Talling et al., 2007; Stow and Bowen, 1980; Lowe, 1982), or the mechanism that triggered and initiated the flow (Middleton and Hampton, 1976; Kneller and Branney, 1995; Khripounoff et al., 2012). We find that flows from different sites can show a very similar behavior, despite marked differences in how flows were triggered or initiated, and in the nature of sediment supply to the system. For instance, once normalized, the flow structure in littoral drift-fed systems (i.e. Monterey and Hueneme Canyons, offshore California) is similar to river-fed systems (i.e. Squamish Prodelta and Var Canyon; Figure 2b), conforming closely to the first end member scenario (rapid increase in velocity followed by exponential decay). Similar turbidity current structures were formed in the Squamish Prodelta, which were initiated by both delta-lip collapses or settling from a surface (homopycnal) plume (Hizzett et al., 2018; Hage et al., 2019), and flows in the Var Canyon caused by plunging (hyperpycnal) sediment-laden river floodwater (Khripounoff et al., 2012). The velocitystructure of these various turbidity currents were also comparable to flows measured in Monterey and Hueneme Canyons, caused by storm wave resuspension and slope failures preconditioned by rapid sediment accumulation (Xu et al., 2010; Paull et al., 2018). Therefore, a wide range of triggers, flow initiation and physiographic systems can lead to very similar flow structure.

Within a single physiographic system, however, multiple flow structures are possible. For example, flows in Congo Canyon are bimodal (Simmons et al., 2020); as some flows are fast with long durations, whereas others are slow with short durations. However, flows from the same source area can also evolve in different ways, depending on their erosional capability and the grainsizes available on the canyon floor (Hage et al., 2019; Heerema et al., 2020), or there may be differences in distance to the source of these flows (Simmons et al., 2020).

\subsection{Does grain size control velocity-time profiles and if so why?}

Rather than triggers or system input type, our results (Figure 2C) suggests that flow structure is primarily governed by the grain size of the sediment that is available for incorporation into the flow. Sand-dominated systems (e.g. Squamish Prodelta, Monterey, Hueneme, and Var Canyons; Figure 2D) exhibit behavior closest to the first end-member. They feature shortduration (minutes to hours) flows, and often show the highest peak velocities (up to $6 \mathrm{~m} / \mathrm{s}$ ) (Figure 1 Panel 1). As sand settles out of suspension more quickly than mud, these sandy flows 
decelerate more rapidly, which in turn drives further loss of sediment - resulting in an exponential decay in flow velocity. Mud-dominated systems (e.g. Congo Canyon; Figure 2D) occur at the opposite end of the spectrum. These flows generally have slower velocities that can be sustained for several hours to days (Figure 3A). 


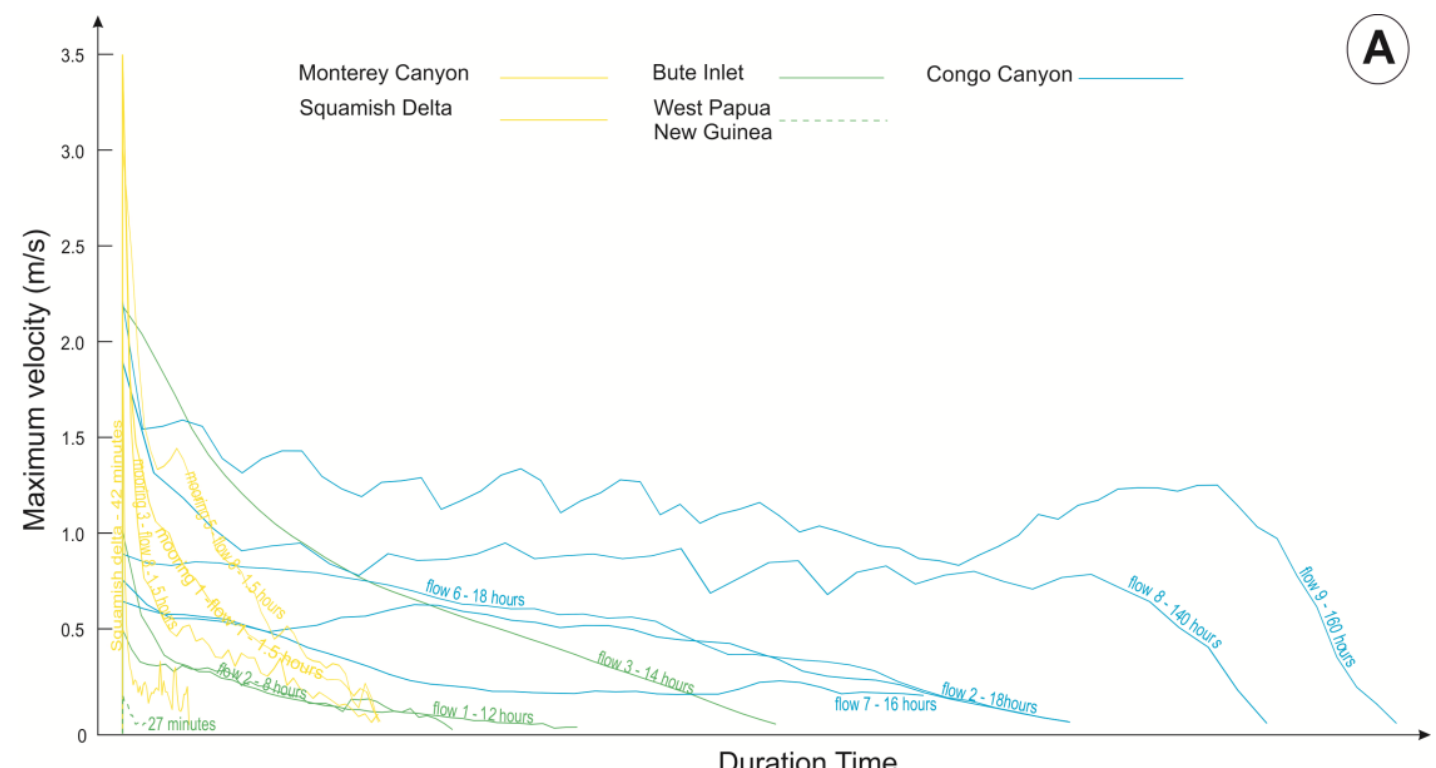

(B)

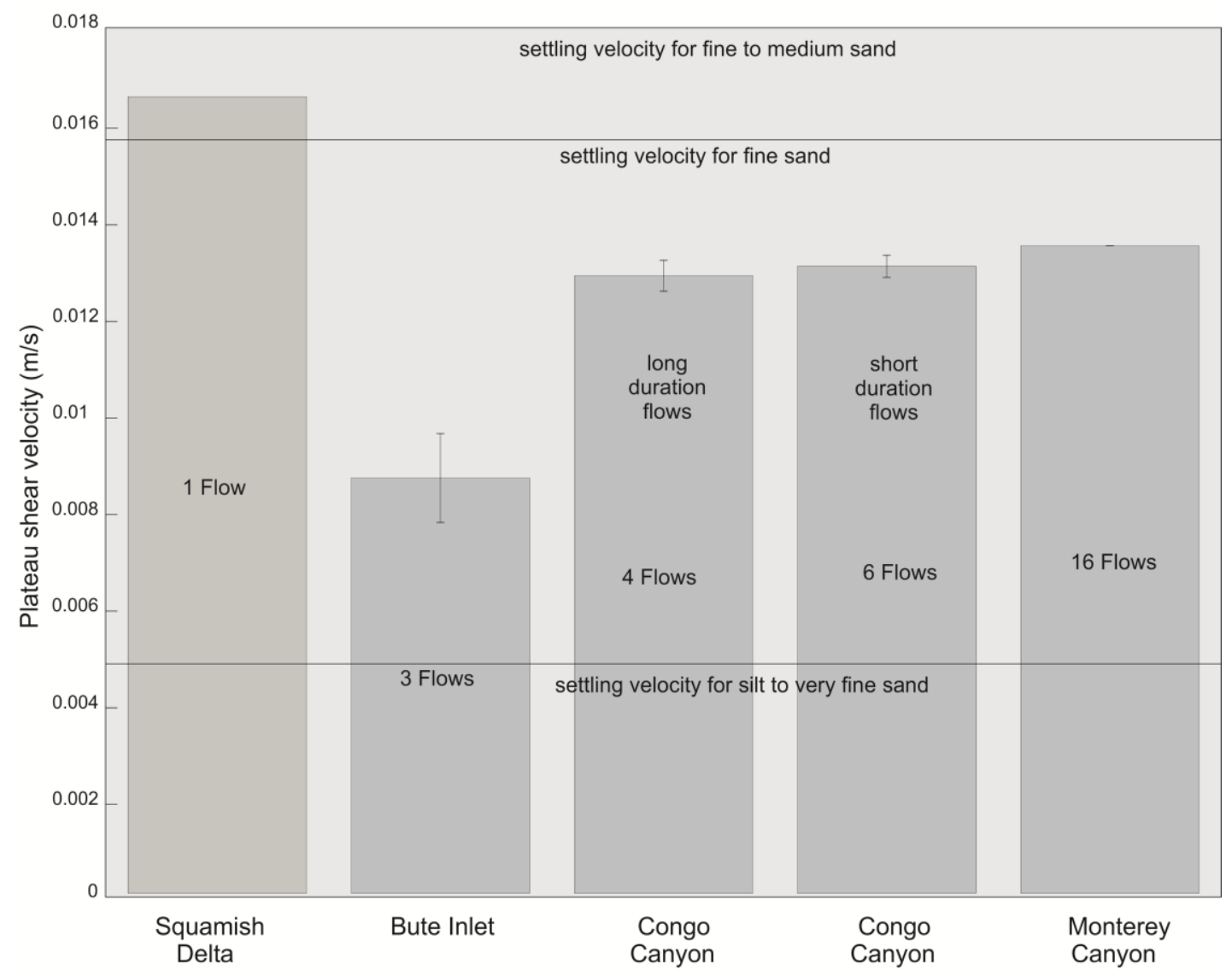

Figure 3: A) comparison between flow duration for some of the events analyzed in this study. B) Cumulative bed shear stress of turbidity currents. In this graph, each block represents the sum of the bed shear stress estimated once each flow is more likely to deposit (plateau-like area). Vertical segments indicate the standard deviation error. For sites such as Squamish Delta, the value of the standard error is missing because the date used herein are relative just to a single flow. Horizontal lines account for the settling velocity threshold relative to silt, fine and medium sand. Refer to the main test for the specification of the values herein considered. 
Muddy sediment is much easier to keep in suspension, and hence slow near-uniform velocities could suspend mud leading to the long duration (Azpiroz-Zabala et al., 2017). The initial peak in velocity is likely to be due to a concentration of sediment in the frontal part of the flow, which is dominantly composed of sand (Simmons et al., 2020). We propose that flow behavior that falls between the two end-members (e.g. Bute Inlet, Cenderawasih Bay; Figure 2D) relates to the ratio of mud and sand within the flow.

We now consider whether the absence of a velocity plateau is caused by the lack of mud (silt and clay-sized fraction) within the flow. If the bed shear stresses fall below the settling velocity of mud $(0.005 \mathrm{~m} / \mathrm{s})$ (Figure $3 \mathrm{~B})$, then this flow would not be capable of suspending mud. Conversely, if the bed shear stresses are higher than the settling velocity of mud, then it is likely that any mud within the flow would be suspended. The calculated bed shear stress of sand-rich turbidity currents (Figure 3B) falls between a minimum of $0.008 \mathrm{~m} / \mathrm{s}$ (Bute Inlet) and a maximum of $0.018 \mathrm{~m} / \mathrm{s}$ (Monterey Canyon). In Congo Canyon, mud-rich flows feature bed shear stresses ranging from $0.012 \mathrm{~m} / \mathrm{s}$ to $0.014 \mathrm{~m} / \mathrm{s}$.

The above analysis demonstrates that the absence of a velocity plateau in some flows is not because they cannot carry fine-grained sediment, rather they do not contain sufficient finegrained sediment to sustain the plateau (Figure 3B). This analysis also suggests that the duration of the velocity plateau relates to the amount of mud in the flow. In fact, the relative durations of the initial velocity peak and the subsequent velocity plateau, may provide a crude proxy for the ratio of sand to mud in a flow. As a result, flow structure may vary within individual systems (e.g. Simmons et al., 2020).

\subsection{Conclusions}

This analysis of turbidity current structure at different sites worldwide, focusing on the temporal evolution of the maximum velocity, shows that flow structure is mainly a function of the grain sizes transported. Knowing the grain size of the sediments within a specific physiographic system thus enables an inference of likely flow structure. This is valuable to studies that focus on geohazards, as the initial dense, sandy portion of the flow will have a different impact to the more sustained plateau. Our findings also have implications for the transport and burial of particles such as organic carbon and pollutants (including microplastics), as they are transported according to their grain size (e.g. Galy et al., 2007; Hage et al., 2020; Pohl et al., 2020; Kane et al., 2020). 


\section{Acknowledgements}

We thank Chevron for access to the exceptional Congo Canyon data set. D. P. and S. M. recognize internal funding via HEIF at the University of Hull. D. P. was supported through funding from the European Research Council (ERC) under the European Union's Horizon 2020 Research and Innovation Programme (Grant Agreement no. 72955). E. P. was supported by a Leverhulme Trust Early Career Fellowship (ECF-2018-267). We acknowledge funding from the Natural Environment Research Council (NERC), including the following Grants: NE/P005780/1， NE/P009190/1， NE/M017540/1， NE/S009965/1， NE/L009358/1, NE/N012798/1, and NE/R015953/1. We also thanks the crews of the RV Heron, Strickland and CCG Vector.

Datasets for this research are included in the following papers with the exception of the Cenderawasih Bay data which are provided as a supplementary data file (filename.csv).

Hughes Clarke, J.E., 2016. First wide-angle view of channelized turbidity currents links migrating cyclic steps to flow characteristics. Nature Communication, 7, 11896. https://doi.org/10.1038/ncomms11896

Hage, S., Cartigny, M.J., Sumner, E.J., Clare, M.A., Hughes Clarke, J.E., Talling, P.J., Lintern, D.G., Simmons, S.M., Silva Jacinto, R., Vellinga, A.J. and Allin, J.R., 2019. Direct monitoring reveals initiation of turbidity currents from extremely dilute river plumes. Geophysical Research Letters, 46. https://doi.org/10.1029/2019GL084526

Hage, S., Galy, V.V., Cartigny, M.J.B., Acikalin, S., Clare, M.A., Gröcke, D.R., Hilton, R.G., Hunt, J.E., Lintern, D.G., McGhee, C. A., Parsons, D.R., Stacey, C.D., Sumner, E.J. and Talling, 2020. Efficient preservation of young terrestrial organic carbon in sandy turbidity current deposits. Geology, 48. https://doi.org/10.1130/G47320.1

Xu, J.P., Swarzenski, P.W., Noble, M. and Li, A.C., 2010. Event-driven sediment flux in Hueneme and Mugu submarine canyons, southern California. Marine Geology, 269 (1-2), 7488

Paull, C.K., Talling, P.J., Maier, K.L., Parsons, D., Xu, J., Caress, D.W., Gwiazda, R., Lundsten, E.M., Anderson, K., Barry, J.P., Chaffey, M., O’Reilly, T., Rosenberger, K.J., Gales, J.A., Kieft, B., McGann, M., Simmons, S.M., McCann, M., Sumner, E.J., Clare, M.A. and Cartigny, M.J., 2018. Powerful turbidity currents driven by dense basal layers. Nature Communications, 9, 4114. https://doi.org/10.1038/s41467-018-06254-6 
Khripounoff, A., Crassous, P., Bue, N.L., Dennielou, B. and Jacinto, R.S., 2012. Different types of sediment gravity flows detected in the Var submarine canyon (northwestern Mediterranean Sea). Progress in Oceanography, 106, 138-153

Simmons, S.M., Azpiroz-Zabala, M., Cartigny, M. J. B., Clare, M. A., Cooper, C., Parsons, D. R., Pope, E. L., Sumner, E. J. and Talling, P. J., 2020. Novel acoustic method provides first detailed measurements of sediment 1 concentration structure within submarine turbidity currents. Geophysical Research: Oceans, 125, e2019JC015904. https://doi.org/10.1029/2019JC015904

Azpiroz-Zabala, M., Cartigny, M.J.B., Talling, P.J., Parsons, D.R., Sumner, E.J., Clare, M.A., Simmons, S.M., Cooper, C., Pope and E.L., 2017. Newly recognized turbidity current structure can explain prolonged flushing of submarine canyons. Science Advances: 3(10), e1700200. DOI: $10.1126 /$ sciadv. 1700200

Wood, J. D., 2013. Ocean Current Measurements at the Elang-1 Location, Cenderawasih Bay, Eastern West Papua, Indonesia, July 2012 to December 2013. Ocean Data Technologies, Inc. technical report prepared for Niko Resources Ltd., Jakarta, Indonesia 


\section{Reference list}

Azpiroz-Zabala, M., Cartigny, M.J.B., Talling, P.J., Parsons, D.R., Sumner, E.J., Clare, M.A., Simmons, S.M., Cooper, C., Pope and E.L., 2017. Newly recognized turbidity current structure can explain prolonged flushing of submarine canyons. Science Advances: 3(10), e1700200. DOI: $10.1126 /$ sciadv. 1700200

Bagnold, R.A., 1962. Auto-suspension of transported sediment; turbidity currents. Proceedings of the Royal Society London, 265, 315-319. https://doi.org/10.1098/rspa.1962.0012

Bongo-Passi, G., 1984. Contribution a' l'e'tude lithostratigraphique, mineralogique etge'ochimique du delta sous-marin profound du fleuve Congo. Universite' de Toulouse, 215 Cantero, M.I., Cantelli, A., Pirmez, C., Balachandar, S., Mohrig, D., Hickson, T.A., Yeh, T., Naruse, H. and Parker, G., 2012. Emplacement of massive turbidites linked to extinction of turbulence in turbidity currents. Nature Geoscience, 5, 42-45. http://doi.org/10.1038/ngeo1320 Clare, M., Lintern, D.G., Rosenberger, K., Hughes Clarke, J.E., Gwiazda, R., Cartigny, M.J., Talling, P.J., Perera, D., Xu, J., Parsons, D., Silva Jacinto, R. and Apprioual, R., 2020. Lessons learned from monitoring of turbidity currents and guidance for future platform designs. Geological Society, London, Special Publications. https://doi.org/10.1144/SP500-2019-173

Cooper, C.K., Andrieux, O. and Wood, J., 2013. Turbidity Current Measurements in the Congo Canyon. In Offshore Technology Conference

Dennieloua, B., Drozb, L., Babonneaub, N., Jacqa, C., Bonnela, C., Picota, M., Le Saouta, M., Saouta, Y., Bezd, M., Savoyea,B., Olue, K. and Rabouillef, C., 2017. Morphology, structure, composition and build-up processes of the active channel-mouth lobe complex of the Congo deep-sea fan with inputs from remotely operated underwater vehicle (ROV) multibeam and video surveys. Deep-Sea Research Part II, 142, 25-49. http://dx.doi.org/10.1016/i.dsr2.2017.03.010

Gales, J.A., Talling, P.T., Cartigny, M.J.B., Hughes Clarke, Lintern, G., Stacey, C. and Clare, M.A., 2019. What controls submarine channel development and the morphology of deltas entering deep-water fjords? Earth Surface Process Landforms, 44, 535-551. https://doi.org/10.1002/esp.4515

Hage, S., Cartigny, M.J., Sumner, E.J., Clare, M.A., Hughes Clarke, J.E., Talling, P.J., Lintern, D.G., Simmons, S.M., Silva Jacinto, R., Vellinga, A.J. and Allin, J.R., 2019. Direct monitoring 
reveals initiation of turbidity currents from extremely dilute river plumes. Geophysical Research Letters, 46. https://doi.org/10.1029/2019GL084526

Hage, S., Galy, V.V., Cartigny, M.J.B., Acikalin, S., Clare, M.A., Gröcke, D.R., Hilton, R.G., Hunt, J.E., Lintern, D.G., McGhee, C. A., Parsons, D.R., Stacey, C.D., Sumner, E.J. and Talling, 2020. Efficient preservation of young terrestrial organic carbon in sandy turbidity current deposits. Geology, 48. https://doi.org/10.1130/G47320.1

Haughton, P.J., Davis, C., McCaffrey, W. and Barker, S., 2009. Hybrid sediment gravity flow deposits - Classification, origin and significance. Marine and Petroleum Geology, 26, 19001918. https://doi.org/10.1016/j.marpetgeo.2009.02.012

Heerema, C., Talling, P.J., Cartigny, M.J.B., Paull, C., Bailey, L., Simmons, S., Parsons, D.R., Clare, M.A., Gwiazda, R., Lundsten, E., Anderson, K., Maier, K.L., Xu, J.P., Sumner, E.J., Rosenburger, K., Gales, J., McGann, M., Carter, L., Pope, E. and Monterey Coordinated Canyon Experiment (CCE) Team, 2020. What determines the downstream evolution of turbidity currents? Earth and Planetary Science Letters, 532, 116023. https://doi.org/10.1594/IEDA/324529

Hickin, E.J., 1989. Contemporary Squamish River sediment flux to Howe Sound, British Columbia. Canadian Journal Earth Science, 26, 1953-1963

Hizzett, J.L., Hughes Clarke, J.E., Sumner, E.J., Cartigny, M.J.B., Talling, P.J. and Clare, M.A., 2018. Which triggers produce the most erosive, frequent and longest runout turbidity currents on deltas? Geophysical Research Letters, 45, 855-863. https://dx.doi.org/10.1002/2017GL075751

Hughes Clarke, J.E., 2016. First wide-angle view of channelized turbidity currents links migrating cyclic steps to flow characteristics. Nature Communication, 7, 11896. https://doi.org/10.1038/ncomms11896

Inman, D.L., Nordstrom, C.E. and Flick, R.E., 1976. Currents in submarine canyons: An airsea-land interaction. Annual Review of Fluid Mechanics, 8 (1), 275-310

Kane, I.A., Clare, M.A., 2019. Dispersion, Accumulation, and the ultimate fate of microplastics in deep-marine environments: a review and futuredDirections. Frontiere Earth Science https://doi.org/10.3389/feart.2019.00080 
Khripounoff, A., Vangriesheim, A., Crassous, P. and Etoubleau, J., 2009. High frequency of sediment gravity flow events in the Var submarine canyon (Mediterranean Sea). Marine Geology, 263 (1-4), 1-6

Khripounoff, A., Crassous, P., Bue, N.L., Dennielou, B. and Jacinto, R.S., 2012. Different types of sediment gravity flows detected in the Var submarine canyon (northwestern Mediterranean Sea). Progress in Oceanography, 106, 138-153

Klaucke, I., Savoye, B., Cochonat, P., 2000. Patterns abd processes of sediments dispersal on the continental slope off Nice, SE France. Marine Geology, 162, 405-422

Kneller, B.C. and Branney, M.J., 1995. Sustained high-density turbidity currents and the deposition of thick massive sands. Sedimentology, 42, 607-616

Lowe, D.R., 1979 b. Sediment gravity flows: their classification and some problems of application to natural flows and deposits, Soc. Econ. Paleontologists Mineralogists Special Publication, 27, 75-82

Lowe, D.R., 1982. Sediment gravity flows; II, depositional models with special reference to the deposits of high-density turbidity currents. Journal of Sedimentary Petrology, 52, 279-297 Maier, K.L., Rosenberger, K., Paull, C.K., Gwiazda, R., Gales, J., Lorenson, T., Barry, J.P., Talling, P.J., McGann, M., Xu, J. and Lundsten, E., 2019b. Sediment and organic carbon transport and deposition driven by internal tides along Monterey Canyon, offshore California. Deep Sea Research Part I: Oceanographic Research Papers, 103-108

Middleton, G.V., 1966. Experiments on density and turbidity currents. I. Motion of the head. Canadian Journal of Earth Science, 3, 523-546

Middleton, G.V. and Hampton, M.A., 1976. Subaqueous sediment transport and deposition by sediment gravity flows, in Stanley, D. J., and Swift, D. J. P., eds., Marine Sediment Transport and Environmental Management. New York, Wiley, 197-218

Mulder, T. and Cochonat, P., 1996. Classification of offshore mass movements. Journal of Sedimentary Research, 66, 43-57

Mulder, T., Syvitskib, J.P.M., Migeonc, S., Fauge`resa, J.C. and Savoye, B. 2003. Marine hyperpycnal flows: initiation, behavior and related deposits. A review. Marine and Petroleum Geology, 20, 861-882. https://doi.org/10.1016/j.marpetgeo.2003.01.003 
Mutti, E., Tinterri, R., Benevelli, G., di Biase, D. and Cavanna, G., 2003. Deltaic, mixed and turbidite sedimentation of ancient foreland basins. Marine and Petroleum Geology, 20 (6-8), 733-755

Orange, D.L., Teas, P.A. and Decker, J., 2010. Multibeam backscatter-insights into marine geological processes and hydrocarbon seepage. Offshore Technology Conference

Parker, G., Fukushima, Y. and Pantin, H.M., 1986. Self-accelerating turbidity currents. Journal of Fluid Mechanisms, 171, 145. https://doi.org/10.1017/S002211208600140

Paull, C.K., Mitts, P., Ussler III, W., Keaten, R. and Greene, H.G., 2005. Trail of sand in upper Monterey Canyon: offshore California. Geological Society America Bulletin,117, 11341145

Paull, C.K., Talling, P.J., Maier, K.L., Parsons, D., Xu, J., Caress, D.W., Gwiazda, R., Lundsten, E.M., Anderson, K., Barry, J.P., Chaffey, M., O’Reilly, T., Rosenberger, K.J., Gales, J.A., Kieft, B., McGann, M., Simmons, S.M., McCann, M., Sumner, E.J., Clare, M.A. and Cartigny, M.J., 2018. Powerful turbidity currents driven by dense basal layers. Nature Communications, 9, 4114. https://doi.org/10.1038/s41467-018-06254-6

Pohl, F., Eggenhuisen, J.T., Kane, I., Clare, M.A., 2020. Transport and burial of microplastics in deep-marine Sediments by turbidity currents. Environmental Science \& Technology, 54 (7), 4180-4189. https://dx.doi.org/10.1021/acs.est.9b07527

Postma, G., 1986. Classification for sediment gravity-flow deposits based on flow conditions during sedimentation. Geology, 14, 291-294

Prior, D.B., Bornhold, B.D., Wiseman, W.J. and Lowe, D.R., 1987. Turbidity current activity in a British Columbia fjord. Science, 237 (4820), 1330-1333

Rabouille, C., Baudin, F., Dennielou, B. and Olu, K., 2017. Organic carbon transfer and ecosystem functioning I the terminal lobes of the Congo deep-sea fan: outcomes of the Congolobe project. Deep-Sea Research Part II, 142, 1-6. http://dx.doi.org/10.1016/j.dsr2.2017.07.006

Savoye, B., Babonneau, N., Dennielou, B. and Bez, M., 2009. Geological over view of the Angola-Congo margin, the Congo deep-sea fan and its submarine valleys. Deep-Sea Research II, 56, 2169-2182. doi:10.1016/j.dsr2.2009.04.001 
Simmons, S.M., Azpiroz-Zabala, M., Cartigny, M. J. B., Clare, M. A., Cooper, C., Parsons, D. R., Pope, E. L., Sumner, E. J. and Talling, P. J., 2020. Novel acoustic method provides first detailed measurements of sediment 1 concentration structure within submarine turbidity currents. Geophysical Research: Oceans, 125, e2019JC015904. https://doi.org/10.1029/2019JC015904

Smith, D.P., Ruiz, G., Kvitek, R., Iampietro, P., 2005. Semiannual patterns of erosion and deposition in upper Monterey Canyon from serial multibeam bathymetry. Geological Society of America Bulletin, 117 (9-10), 1123-1133

Symons, W.O., Sumner, E.J., Paull, C.K., Cartigny, M.J., Xu, J.P., Maier, K.L., Lorenson, T.D. and Talling, P.J., 2017. A new model for turbidity current behavior based on integration of flow monitoring and precision coring in a submarine canyon. Geology, 45 (4), 367-370

Syvitski, J.P.M, Smith, J.N., Calabrese, E.A., Boudreau, B.P., 1988. Basin sedimentation and the growth of prograding deltas. Journal of Geophysical Research, 93 (No. C6), 6895-6908

Stow, D.V., Bowen, A.J., 1980. A physical model for the transport and sorting of fine-grained sediment by turbidity currents. Sedimentolgy, 27, 31-46

Talling, P. J., Wynn, R. B., Masson, D. G., Frenz, M., Cronin, B. T., Schiebel, R., and Amy, L. A., 2007. Onset of submarine debris flow deposition far from original giant landslide. Nature, 450, 541-544

Talling, P.J., Masson, D.G., Sumner, E.J. and Malgeisni, G., 2012. Subaqueous sediment density flows: Depositional processes and deposit types. Sedimentology. https://doi.org/10.1111/j.1365-3091.2012.01353.x

Talling, P.J., Paull, C.K., and Piper, D.J., 2013. How are subaqueous sediment density flows triggered, what is their internal structure and how does it evolve? Direct observations from monitoring of active flows. Earth-Science Reviews, 125, 244-287

Talling, P. J., 2014. On the triggers, resulting flow types and frequencies of subaqueous sediment density flows in different settings. Marine Geology, 352, 155-182

Vendettuoli, D., Clare, M.A., Clarke, J.H., Vellinga, A., Hizzet, J., Hage, S., Cartigny, M.J.B., Talling, P.J., Waltham, D., Hubbard, S.M. and Stacey, C., 2019. Daily bathymetric surveys document how stratigraphy is built and its extreme incompleteness in submarine channels. Earth and Planetary Science Letters, 515, 231-247. https://doi.org/10.1016/j.eps1.2019.03.033 
Wood, J. D., 2013. Ocean Current Measurements at the Elang-1 Location, Cenderawasih Bay, Eastern West Papua, Indonesia, July 2012 to December 2013. Ocean Data Technologies, Inc. technical report prepared for Niko Resources Ltd., Jakarta, Indonesia

Xu, J.P., Swarzenski, P.W., Noble, M. and Li, A.C., 2010. Event-driven sediment flux in Hueneme and Mugu submarine canyons, southern California. Marine Geology, 269 (1-2), 7488

Zeng, J., Lowe, D.R., Prior, D.B., Wiseman JR, W.J. and Bornhold, B.D., 1991. Flow properties of turbidity currents in Bute Inlet, British Columbia. Sedimentology, 38 (6), 975996 